\title{
A New 5-Alkenylresorcinol Sch 725681 from Aspergillus sp.
}

\author{
Shu-Wei Yang, Tze-Ming Chan, Joseph Terracciano, ${ }^{\dagger}$ David Loebenberg, \\ Mahesh Patel, ${ }^{\dagger \dagger}$ Vincent Gullo, ${ }^{\dagger \dagger}$ Min $\mathrm{Chu}^{\dagger}$
}

Received: January 20, 2006 / Accepted: February 15, 2006

(C) Japan Antibiotics Research Association

\begin{abstract}
A new 5-alkenylresorcinol Sch725681 (1) was isolated and identified from the culture of an Aspergillus sp. The structure elucidation of $\mathbf{1}$ was accomplished based on extensive NMR spectroscopic analyses. Compound $\mathbf{1}$ showed inhibitory activity against Saccharomyces cerevisiae (PM503) and Candida albicans (C43) with MICs of 16 and $64 \mu \mathrm{g} / \mathrm{ml}$, respectively.
\end{abstract}

Keywords antifungal, antimicrobial, structure elucidation

A number of resorcinols (1,3-dihydroxyalkylbenzenes) have been isolated from plants [1], marine organisms [2], and microorganisms [3 6]. Many of them have been described to exhibit activities against various therapeutic targets, such as cleavage of DNA [1] and inhibition of glycosidase [4], HIV protease [6] and glycerol-3-phosphate dehydrogenase [3]. Some resorcinols have also been reported to display antifungal [7,8], antibacterial [7], and cytotoxic activities [9].

In the course of our continuing search for novel antimicrobial agents [10], we have isolated a novel antimicrobial 5-alkenylresorcinol Sch 725681 (1), from an Aspergillus sp. culture (SPRI-0784). Sch725681 was identified as a new 5-alkenylresorcinol based on extensive NMR spectroscopic analyses. In this paper, we report the isolation, structure elucidation and antimicrobial activity of 1 .
Fermentation studies of Aspergillus sp. culture SPRI0784 were conducted in shake flasks. Stock cultures were maintained as frozen whole broths at $-80^{\circ} \mathrm{C}$ in a final concentration of $10 \%$ glycerol. The germination medium contained Proteus Peptone (5.0 g/liter), $\mathrm{NaCl}(5.0 \mathrm{~g} /$ liter $)$, $\mathrm{KH}_{2} \mathrm{PO}_{4}(5.0 \mathrm{~g} /$ liter $)$, Yeast Extract ( $3.0 \mathrm{~g} /$ liter $)$, Cerelose $(20.0 \mathrm{~g} /$ liter $)$, and Soybean Grits $(5.0 \mathrm{~g} /$ liter $)$. The $\mathrm{pH}$ was adjusted to 7.0 prior to autoclaving. Each $250 \mathrm{ml}$ Erlenmeyer flask containing $70 \mathrm{ml}$ of this medium was inoculated with $2 \mathrm{ml}$ of the stock culture. The flasks were incubated at $24^{\circ} \mathrm{C}$ on a rotary shaker at $250 \mathrm{rpm}$ for 96 hours. This seed culture $(2.5 \mathrm{ml})$ was used to inoculate a second stage seed in $250 \mathrm{ml}$ Erlenmeyer flasks, each containing $70 \mathrm{ml}$ of the same seed medium and the flasks were incubated as above for 96 hours.

This second stage seed was then used to inoculate the fermentation medium at $5 \% \mathrm{v} / \mathrm{v}$. The fermentation was carried out in $500 \mathrm{ml}$ Erlenmeyer flasks, each containing $100 \mathrm{ml}$ of the fermentation medium, containing Neopeptone (10.0 g/liter) and Cerelose ( $40.0 \mathrm{~g} /$ liter). The $\mathrm{pH}$ was adjusted to 7.4 and $\mathrm{CaCO}_{3}, 4.0 \mathrm{~g} /$ liter was added. The flasks were incubated at $24^{\circ} \mathrm{C}$ on a rotary shaker at $250 \mathrm{rpm}$ for 168 hours.

The harvested fermentation broth (1.0 liter) was stirred with $0.2 \mathrm{~kg}$ of $\mathrm{NaCl}$ and 2.0 liters of acetonitrile $(\mathrm{MeCN})$ for 15 minutes. The organic layer was separated and concentrated to a slurry in vacuo. The slurry material was absorbed onto the polymeric resin, CG161 $(\sim 100 \mathrm{ml}$, Tosoh Biosep LLC, Montgomeryville, PA, USA) and the
S.-W. Yang (Corresponding author), T.-M. Cjan, J. Terracciano, D. Loebenberg, M. Patel, V. Gullo, M. Chu: Schering-Plough Research Institute, 2015 Galloping Hill Road, Kenilworth, NJ 07033, USA, E-mail: shu-wei.yang@spcorp.com
† Present address: Cubist Pharmaceuticals, Inc. 65 Hayden Ave. Lexington, MA 02421, USA

${ }^{\dagger}$ Present address: Cetek Corporation, 260 Cedar Hill St. Marlborough, MA 01752, USA

${ }^{\dagger \dagger}$ Present address: SMP International LLC, 42 Brentwood Drive, Verona, NJ 07044, USA 
salts and hydrophilic substances were removed by washing with 1 liter of water. Then, the absorbed organic material was eluted with $85 \%$ aq. $\mathrm{MeOH}$ ( 1 liter) to yield $\sim 0.8 \mathrm{~g}$ of dried material after removing solvent in vacuo. This organic material was purified on a semi-preparative ODS-A HPLC column (YMC, $120 \AA$, S-7, $20 \mathrm{~mm} \times 250 \mathrm{~mm}$ ). The column was eluted with a gradient of $\mathrm{MeCN}-\mathrm{H}_{2} \mathrm{O}$ : $5 \sim 100 \% \mathrm{MeCN}$ in 35 minutes, and then isocratically with $100 \% \mathrm{MeCN}$ for another 15 minutes, with a flow rate of $15 \mathrm{ml} /$ minute and the eluate was collected in $13 \mathrm{ml}$ fractions. An enriched complex containing $1(\sim 10 \mathrm{mg})$ was obtained with two injections of $40 \mathrm{mg}$ each of the crude material. The complex was further purified using another HPLC C-18 column (YMC Pro C18, $3 \mu \mathrm{m}, 4.6 \times 50 \mathrm{~mm}$ ). The column was eluted with a isocratic $10 \%$ aq. $\mathrm{MeCN}$ solution for 2 minutes followed by a gradient of $10 \sim 100 \%$ $\mathrm{MeCN}$ solution in 13 minutes with a flow rate of $1 \mathrm{ml} /$ minute and the desired peak containing pure 1 was collected. Combined pure $1(\sim 3 \mathrm{mg})$ was obtained at a retention time $\sim 10$ minutes with five injections of $\sim 2 \mathrm{mg}$ each of the enriched material.

The structure of 1 was mainly elucidated by extensive 1D and 2D NMR analyses. In the ${ }^{1} \mathrm{H}-\mathrm{NMR}$ spectra, 18 proton signals were observed. Four aliphatic methylene and one methyl signals were observed in the upfield region, and six resonances with a total intensity indicating seven protons were observed in the olefinic/aromatic region. In the ${ }^{13} \mathrm{C}$ NMR spectrum, only thirteen carbon signals were observed. However, two signals ( $\delta 108.1$ and $\delta 159.5)$ had approximately twice the intensity of the other signals, indicating a symmetric portion in the structure of the molecule. The coupling patterns of the two signals $(\delta 6.12$, $2 \mathrm{H}, \mathrm{d}, J=2.2 \mathrm{~Hz}$ and $\delta 6.07,1 \mathrm{H}, \mathrm{t}, J=2.2 \mathrm{~Hz}$ ) in the most downfield region of ${ }^{1} \mathrm{H}-\mathrm{NMR}$ represented a pattern typical of a 1,3-dihydroxy-5-alkylbenzene moiety. The carbon chemical shift at $\delta 159.5(2 \times \mathrm{C})$ represented two hydroxylsubstituted aromatic carbons (C-1 and C-5). Therefore, the basic skeleton was proposed as 5-alkyl- or 5-alkenylresorcinol. The molecular formula of $\mathbf{1}$ was calculated as $\mathrm{C}_{15} \mathrm{H}_{20} \mathrm{O}_{2}$ which is consistent with a negative ESI-MS measurement $\left(\mathrm{m} / \mathrm{z} 231,[\mathrm{M}-\mathrm{H}]^{-}\right)$. Excluding the six aromatic carbons, there were four olefinic protonated carbon signals remaining in the downfield region in the ${ }^{13} \mathrm{C}$

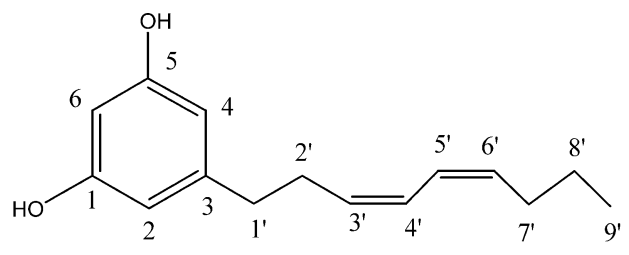

Sch 725681(1)

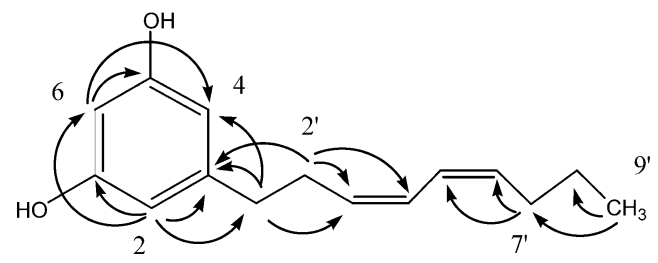

Fig. 1 Key HMBC correlations of 1.

Table 1 NMR spectral data for compound 1 in $\mathrm{CD}_{3} \mathrm{OD}^{\mathrm{a}}$

\begin{tabular}{|c|c|c|c|}
\hline $\mathrm{C} / \mathrm{H}$ no. & ${ }^{1} \mathrm{H}(\delta)$ & ${ }^{13} \mathrm{C}(\delta)$ & HSQC-TOCSY \\
\hline 1,5 & & $159.5 \mathrm{~s}$ & \\
\hline 2,4 & $6.12,2 \mathrm{H}, \mathrm{d}, J=2.2$ & $108.1 \mathrm{~d}$ & $C-6^{b}$ \\
\hline 3 & & $145.6 \mathrm{~s}$ & \\
\hline 6 & $6.07,1 \mathrm{H}, \mathrm{t}, J=2.2$ & $101.3 \mathrm{~d}$ & $\mathrm{C}-2^{\mathrm{b}}, \mathrm{C}-4^{\mathrm{b}}$ \\
\hline $1^{\prime}$ & $2.50,2 \mathrm{H}, \mathrm{t}, J=7.3$ & $37.3 t$ & $\mathrm{C}-2^{\prime}$ \\
\hline $2^{\prime}$ & $2.29,2 \mathrm{H}, \mathrm{q}, J=7.3$ & $35.6 \mathrm{t}$ & $\mathrm{C}-1^{\prime}, \mathrm{C}-3^{\prime}$ \\
\hline $3^{\prime}$ & $5.56,1 \mathrm{H}, \mathrm{m}, J=10.8,7.3$ & $132.3 d$ & $\mathrm{C}-2^{\prime}, \mathrm{C}-4^{\prime}$ \\
\hline $4^{\prime}$ & $6.00,1 \mathrm{H}, \mathrm{brdd}, J=10.8,10.5$ & $132.3 d$ & $\mathrm{C}-2^{\prime b}, \mathrm{C}-3^{\prime}, \mathrm{C}-5^{\prime}$ \\
\hline $5^{\prime}$ & $5.97,1 \mathrm{H}, \mathrm{brdd}, J=10.8,10.5$ & $132.1 \mathrm{~d}$ & $C-4^{\prime}, C-6^{\prime}$ \\
\hline $6^{\prime}$ & $5.53,1 \mathrm{H}, \mathrm{m}, J=10.8,7.3$ & $133.3 d$ & $\mathrm{C}-5^{\prime}, \mathrm{C}-7^{\prime}$ \\
\hline $7^{\prime}$ & $2.01,2 \mathrm{H}, \mathrm{q}, J=7.3$ & $35.9 t$ & $C-6^{\prime}, C-8^{\prime}, C-9^{\prime b}$ \\
\hline $8^{\prime}$ & $1.39,2 \mathrm{H}$, hex, $J=7.3$ & $23.8 \mathrm{t}$ & $\mathrm{C}-7^{\prime}, \mathrm{C}-9^{\prime}$ \\
\hline $9^{\prime}$ & $0.89,3 \mathrm{H}, \mathrm{t}, J=7.3$ & $14.1 \mathrm{q}$ & $C-8^{\prime}, C-7^{\prime b}$ \\
\hline
\end{tabular}

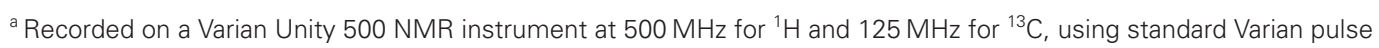
sequence programs (VNMR Version 6.1 Software). $\delta$ in ppm; $J$ in $\mathrm{Hz}$.

${ }^{b}$ Three-bond correlation. 
NMR spectrum, indicating two double bonds in the chain moiety. The HSQC-TOCSY data listed in Table 1 strongly suggested a linear chain moiety based on the analysis of ${ }^{1} \mathrm{H}-{ }^{13} \mathrm{C}$ correlations from $\mathrm{C}-1^{\prime}$ through $\mathrm{C}-9^{\prime}$, which are all proton attached carbons. The location of the two double bonds and the straight chain structure were thus determined. The coupling constants $(J=10.8 \mathrm{~Hz})$ between $\mathrm{H}-3^{\prime}$ and $\mathrm{H}-4^{\prime}$ and between $\mathrm{H}-5^{\prime}$ and $\mathrm{H}-6^{\prime}$ established the cis configuration of both $\Delta 3^{\prime}, 4^{\prime}$ and $\Delta 5^{\prime}, 6^{\prime}$. The connectivity of the alkenyl chain to aromatic ring was confirmed based on the long-range heteronuclear shift correlations of H-1' $(\delta 2.50)$ to $\mathrm{C}-2(\delta$ 108.1), C-3 $(\delta$ 145.6) and C-4 $(\delta$ 108.1) observed in the HMBC spectrum. Finally, the proposed structure was confirmed by HMBC data as shown in Fig. 1. Thus compound 1 was determined to be 5-[(3Z,5Z)-3,5-nonadienyl]-1,3benzenediol. Unambiguous assignment of the proton and carbon chemical shifts was achieved based on 2D NMR data analyses including HSQC, HSQC-TOCSY, and HMBC as detailed in Table 1.

Previously reported 5-alkenylresorcinols usually have isolated double bond(s) in the chain portion of the molecule $[1,2,5]$. Conjugated double bonds in the chain moiety for resorcinols are unusual. Sch725681 (1) represents a unique example of a 5-alkenylresorcinol having conjugated double bonds both with cis configurations in the chain moiety.

Sch725681 (1) displayed antifungal activity against Saccharomyces cerevisiae (PM503) [11] and Candida albicans (C43) with MICs of 16 and $64 \mu \mathrm{g} / \mathrm{ml}$, respectively. Compound 1 also showed antibacterial activity against Staphylococcus aureus at $64 \mu \mathrm{g} / \mathrm{ml}$. This result indicated that compound $\mathbf{1}$ does not have a significant selective antimicrobial profile.

Acknowledgement The authors are grateful to Mr. Lewis B. Fan for extract preparation and Mr. Ross Yang for MS measurement.

\section{References}

1. Related references were cited here: Lytollis W, Scannell RT, An H, Murty VS, Reddy KS, Barr JR, Hecht SM. 5Alkylresorcinols from Hakea trifurcate that cleave DNA. J Am Chem Soc 117: 12683-12690 (1995)

2. Barrow RA, Capon RJ. Alkyl and alkenyl resorcinols from an Australian marine sponge, Haliclona sp. (Haplosclerida: Haliclonidae). Aust J Chem 44: 1393-1405 (1991)

3. Tsuge N, Mizokami M, Imai S, Shimazu A, Seto H. Adipostatins A and B, new inhibitors of glycerol-3phosphate dehydrogenase. J Antibiot 45: 886-891 (1992)

4. Yamada H, Shiomi K, Xu Q, Nagai T, Shibata M, Oya I, Takahashi Y, Ōmura S. New Glycosidases inhibitors, panosialins D and wD produced by Streptomyces sp. OH5186. J Antibiot 48: 205-210 (1995)

5. Matsuzaki K, Tahara H, Inokoshi J, Tanaka H, Masuma R, Ömura S. New brominated and halogen-less derivatives and structure-activity relationship of azaphilones inhibiting gp120-CD4 binding. J Antibiot 51: 1004-1011 (1998)

6. Dolak LA, Seest EP, Cialdella JI, Li GP, Bohanon MJ. Compounds used for the inhibition of HIV-protease. PCT WO 93/04055A2. March 4, 1993

7. Orabi KY, Mossa JS, El-Feraly FS. Isolation and characterization of two antimicrobial agents from mace (Myristica fragrans). J Nat Prod 54: 856-859 (1991)

8. Garcia S, Garcia C, Heinzen H, Moyna P. Chemical basis of the resistance of barley seeds to pathogenic fungi. Phytochemistry 44: 415-418 (1997)

9. Filip P, Anke T, Sterner O. 5-(2'-Oxoheptadecyl)-resorcinol and 5-(2'-oxononadecyl)-resorcinol, cytotoxic metabolites from a wood-inhabiting basidiomycete. Zeitschrift fur Naturforschung Section C 57: 1004-1008 (2002)

10. Related references were cited here: Yang SW, Chan TM, Terracciano J, Loebenberg D, Patel M, Chu M. Structure elucidation of Sch 725674 from Aspergillus sp. J Antibiot 58: 535-538 (2005)

11. Yang SW, Chan TM, Pomponi SA, Chen G, Loebenberg D, Wright A, Patel M, Gullo V, Pramanik B, Chu M. Structure elucidation of a new antifungal sterol sulfate, Sch 575867, from a deep-water marine sponge (Family: Astroscleridae). J Antibiot 56: 186-189 (2003) 